\title{
IZNIMNO ZAKONSKO PROPISIVANJE KAŽNJIVOSTI POKUŠAJA
}

\author{
UDK: 343.23 (497. 5) \\ Pregledni rad \\ Primljeno: 1.03. 2016.
}

Opće pravilo o kažnjavanju i kažnjivosti pokušaja kaznenog djela zasebno je normirano u okviru materijalnog kaznenog zakonika, koji istovremeno propisuje i brojne slučajeve posebnog kažnjavanja pokušaja, onda kada nije moguće primijeniti osnovno pravilo koje se oslanja na zapriječenu kaznu za pojedino kazneno djelo.

Posebno pravno pravilo o kažnjivosti pokušaja normirano je kroz odrednicu ,ako zakon izričito propisuje kažnjavanje i za pokušaj“.

U ovome radu autor detaljno prikazuje i raščlanjuje sve posebne pojavne oblike kažnjivosti pokušaja, utvrđujući njihovu zastupljenost, katalog u hrvatskom kaznenom zakonodavstvu, uspoređujući težine izvorno zapriječenih kazni za pojedino kazneno djelo za koje je iznimno kažnjiv pokušaj i analizirajući njihovu zastupljenost po svakom pojedinom dijelu kaznenog zakonika.

Zaključno se ističe kako se zakonodavac odlučio posebno kažnjavati pokušaj i kod kaznenih djela iz domene tzv. bagatelnog kriminaliteta, sa zapriječenom kaznom zatvora do jedne godine, uz brojna kaznena djela sa zapriječenom kaznom zatvora do tri godine, što ukazuje na opravdanost zakonodavnog rješenja da je neophodno inkriminirati posebne slučajeve kada pokušaj kaznenog djela mora biti kažnjen, iako se nalaze izvan domašaja općeg pravila o kažnjivosti pokušaja.

\section{Ključne riječi: pokušaj, iznimno normiranje, zakonsko propisivanje kažnjivosti pokušaja}

\section{UVODNA RAZMATRANJA}

Kazneno zakonodavstvo donosi, propisuje dva načina kažnjavanja nastojanja ostvarivanja bića određenog kaznenog djela, konkretno izričito normiranje i iznimno ili posebno propisivanje pojedinačnih slučajeva kažnjivosti pokušaja. Izrijekom se općenito kažnjava namjerno poduzimanje radnji koje prostorno i vremenski prethode neposrednom ostvarenju bića djela ukoliko je za dotično kazneno djelo zapriječena kazna zatvora u trajanju od pet godina ili teža kazna. Posebno, izuzetno, ali ne i mnogo rjeđe, zakonskim putem je normirana kažnjivost

1 Bruno Moslavac, zamjenik općinskog državnog odvjetnika u Virovitici, Kazneni odjel. Ovaj rad izrađen je sukladno odredbi čl. 120., st. 5. Zakona o državnom odvjetništvu (NN 76/09, 153/09, 116/10, 145/10, 57/11, 130/11, 72/13, 148/13, 33/15 i 82/15; u daljnjem tekstu: ZDO). Svi stavovi i mišljenja izneseni u radu isključivo su stavovi i mišljenja autora i niti na koji način ne predstavljaju niti jesu stavovi i mišljenja institucije u kojoj je autor zaposlen. 
pokušaja u odgovarajućim slučajevima, očigledno po zakonodavcu ocijenjenim kao značajnim za sankcioniranje nekog protupravnog ponašanja označenog kaznenim djelom. Pokušaj se kažnjava, dakle, u pravilu kod težih kaznenih djela, sa zapriječenom kaznom zatvora u trajanju od pet godina ili strožom kaznom. „Nisu pokušaji svih kaznenih djela opasni i kažnjivi. Riječ je o kažnjivom ulasku u zonu ostvarenja zakonskih obilježja samo težih kaznenih djela (za koja se može izreći kazna zatvora od pet godina ili teža kazna), a iznimno i za lakša kaznena djela kada zakon izričito propisuje kažnjavanje i za pokušaj.“”2

\section{OSNOVNI ELEMENTI POKUŠAJA}

\section{1. Biće i pojam pokušaja}

Pokušaj je kaznenog djela poseban odsjek iz cjelokupne dinamike kriminalnog ponašanja, sadržajem smješten između pripremnih radnji i dovršenog kaznenog djela. Karakterizira ga okolnost da je počinitelj s namjerom započeo, poduzeo odgovarajuće radnje koje prostorno i vremenski prethode ostvarenju bića propisanog kaznenog djela, ali nije dovršio počinjenje kaznenog djela, nije ga izvršio. ${ }^{3}$ Bit, srž pokušaja nalazimo u opasnosti kaznenog djela i u opasnosti počinitelja, stoga se pokušaj kao nedovršeno kazneno djelo javlja kao realno ugrožavanje zaštićenog dobra i kao opasna volja usmjerena ka jednom zaštićenom dobru, ali bez realizacije napada. ${ }^{4}$ Pokušaj kao kažnjiva radnja načelno postoji kada se opća zakonska norma o pokušaju iz čl. 34. Kaznenog zakona (NN 125/11, 144/12, 56/15 i 61/15 - ispr.; u daljnjem tekstu: KZ) poveže s odgovarajućom odrednicom iz posebnog dijela općeg kaznenog materijalnog zakona koja konstituira zakonski opis određenog kaznenog djela. ${ }^{5}$ Iznimka su slučajevi posebnog propisivanja kažnjivosti pokušaja, predviđeni u posebnom dijelu KZ-a, uz pojedina kaznena djela ili pojedine pojavne oblike određenih kaznenih djela. Počinitelj pokušaja kaznenog djela mora htjeti, imati namjeru, ostvarenja djela, stoga je ista namjera kod pokušaja i kod dovršenog djela ${ }^{6}$ Objektivni dio ili sastojnica pokušaja jest započinjanje ostvarenja bića kaznenog djela, ${ }^{7}$ odnosno, poduzimanje radnji koje prostorno i vremenski

\footnotetext{
Horvatić, Ž., (1997.), Novo hrvatsko kazneno pravo, Organizator, Zagreb, str. 216.

3 Bačić, F., (1995.), Krivično pravo - opći dio, Informator, Zagreb, str. 249.

4 Ibid, str. 250-251.

5 Prema: ibid, str. 252.

6 Prema: Novoselec, P., „Razgraničenje pripremnih radnji i pokušaja“, Zbornik Pravnog fakulteta Sveučilišta u Rijeci, (1991.), v. 29, br. 2, str. 722.

Ibid, str. 740.
} 
neposredno prethode ostvarenju kaznenog djela, ${ }^{8}$ pod daljnjim zakonskim uvjetima. Naglasak je na okolnosti da odnosne radnje počinitelj doista mora izvesti, pokrenuti počinjenje kaznenog djela. „Da bi postojao pokušaj, moraju se ostvariti tri nužna obilježja: mora postojati namjera, mora se započeti ostvarenje kaznenog djela i djelo ne smije biti dovršeno.“9 „Negativna je pretpostavka pokušaja da kazneno djelo nije dovršeno. “10 Novim uređenjem pokušaja napuštena je formalno-objektivna teorija zastupljena u ranije važećem Kaznenom zakonu, ${ }^{11}$ prema kojoj je pokušaj postojao ako je počinitelj s namjerom započeo izvršenje kaznenog djela, ali ga nije dovršio. ${ }^{12}$ Novim se zakonskim sadržajem postojanje pokušaja premješta i na radnje koje prostorno i vremenski neposredno prethode ostvarenju bića kaznenog djela. ${ }^{13}$ Formulacija pokušaja u čl. 34., st. 1. KZ-a utemeljena je na individualnoobjektivnoj teoriji. ${ }^{14}$ „Radnju poduzetu prostorno i vremenski neposredno prije početka ostvarenja bića kaznenog djela nužno je razlikovati ${ }^{15}$ od radnje iz bića kaznenog djela, pri tome vodeći računa o postojanju precizno utvrđenih kriterija razlikovanja i polazeći od toga da radnja izvan bića kaznenog djela bitno participira u genezi ostvarenja kaznenog djela; izvan je bića kaznenog djela, ali s doprinosom značenja zbog kojeg država poseže za ius puniendi. "“16

8 ,Sud prvog stupnja je, pravilno, utvrdio da je optuženik bio svjestan što čini. Planirano i hladnokrvno napao je oštećenika mačetom, udarajući ga po vitalnim dijelovima tijela. Cilj je bio ubiti oštećenika i tako se osvetiti što ga je ostavila dugogodišnja djevojka. Takav motiv za osvetom, prema općeprihvaćenim moralnim zasadama društva, čini osvetu bezobzirnom. Optuženik je poduzeo sve radnje koje prostorno i vremenski neposredno prethode ostvarenju bića kaznenog djela teškog ubojstva iz bezobzirne osvete, a od napada je odustao nakon što se oštećenik povukao u stan." (VSRH broj: I Kž 403/2014-6 od 14. listopada 2014.)

9 Novoselec, P. (2004.), Opći dio kaznenog prava, Sveučilište u Zagrebu, Zagreb, str. 274. Isto: Bačić, F. - Pavlović, Š. (2004.), Komentar Kaznenog zakona, Organizator, Zagreb, str. 129 i dalje.

10 Horvatić, Ž. (1997.), Rječnik kaznenog prava, Masmedia, Zagreb, str. 397.

11 NN 110/97, 27/98 - ispr., 50/00, 129/00, 51/01, 111/03, 190/03 - Odluka USRH, 105/04, 84/05 ispr., 71/06, 110/07 i 152/08. Dalje: KZ/97.

12 Pavlović, Š., „Razgraničenje pripremnih radnji i pokušaja prema novom Kaznenom zakonu“, Hrvatski ljetopis za kazneno pravo i praksu (Zagreb), vol. 19, broj 2/2012, str. 690.

13 Ibid, str. 691.

14 Ibid, str. 692. Prema navedenoj teoriji, pokušaj započinje radnjom koja neposredno prethodi radnji kojom se ostvaruje neko od zakonom određenog obilježja kaznenog djela, pri čemu između tih dviju radnji postoji bliski prostorni i vremenski kontinuitet, bez ikakve intermisije ili interakcije izvan tog odnosa. Radnja mora biti drugačija od radnje počinjenja iz bića kaznenog djela, ali s njom mora logički i životno činiti čvrstu cjelinu. Prema: ibid, str. 698. Isto i: Horvatić (1997.), ibid, str. 397.

15 „Za kvalifikaciju neke radnje kao bludne radnje poduzete u cilju zadovoljenja spolnog nagona nije nužno da ista podrazumijeva diranje po intimnim dijelovima tijela." (ŽsVž broj: Kž-199/12 od 7. kolovoza 2012.)

16 Ibid, str. 698. 


\section{2. Trenutak početka ostvarivanja zakonskih obilježja bića određenog kaznenog djela}

Ključan element za utvrđivanje pokušaja jest određivanje početka izvršenja kaznenog djela, odnosno trenutka kada je počinitelj započeo s ostvarivanjem zakonskih obilježja bića određenog kaznenog djela. ${ }^{17}$ Navedeni trenutak ključan je za odgovor na pitanje razgraničenja pripremnih radnji, nekažnjivog ponašanja, od pokušaja kaznenog djela, koji ulazi u kažnjivu zonu. ${ }^{18}$ Pokušaj čine sve one aktivnosti koje prethode „konačnom napadu“, završnoj akciji počinitelja i s njom čine logičnu i čvrstu cjelinu, tako da se po prirodi stvari pojavljuju kao početak napada na zaštićeni objekt. ${ }^{19}$ Točna formula za izračunavanje, posljedično i razgraničenje pripremnih radnji od pokušaja, trenutka ulaženja počinitelja u fazu počinjenja kaznenog djela, ne postoji i uvijek ce biti sumnji, ${ }^{20}$ koje treba rješavati u svakom pojedinačnom slučaju koji se pojavi u sudskoj praksi. Bar djelomično ostvarenje bića kaznenog djela, u sudskoj je praksi misao vodilja prilikom ocjene postojanja pokušaja. Prilikom ocjene radi li se o pokušaju ili ne, sud mora voditi računa o konkretnom događaju i svim elementima bića kaznenog djela koje je predmetom optužbe..$^{21}$

\section{3. Uvodne osnove načela legaliteta}

Zakonska formula, prema kojoj pokušaj postoji ili nastaje u trenutku kad počinitelj poduzme određenu radnju ili radnje koje prostorno i vremenski neposredno prethode ostvarenju bića odgovarajućeg kaznenog djela. ${ }^{22}$ Načelo legaliteta zahtijeva da se pokušaj shvati kao oblik izražavanja kaznenog djela i da može početi jedino u trenutku kada ili gdje počinjene ostvarivanje zakonskog bića određenog kaznenog djela. ${ }^{23}$ Osnovna zakonska odrednica o pokušaju ne smije biti temelj za proširenje kažnjivosti izvan sadržaja bića određenog kaznenog djela, u

17 Bačić (1995.), ibid.

18 Ibid.

19 Ibid, str. 253.

20 Ibid, str. 254.

21 „Sama uporaba fizičke sile u vidu hvatanja za obje ruke oštećenice još ne znači da se radi o početku izvršenja kaznenog djela silovanja, jer u činjeničnom opisu izostaje naznaka bilo kakve konkretne radnje okrivljenika usmjerene na zadovoljenje njegovog spolnog nagona. Navod izreke da je okrivljenik želio s oštećenicom stupiti u spolni odnos opisuje isključivo subjektivnu stranu bića predmetnog kaznenog djela, što samo po sebi, kraj izostanka opisa bilo kakve konkretne radnje kojom bi se zadiralo u seksualni integritet oštećenice, nije dovoljno da obuhvati zakonski smisao inkriminacije.“ (VSRH broj: Kžm48/2011 od 6. rujna 2012.)

22 Bačić (1995.), ibid, str. 255.

23 Ibid. 
smislu da se kao pokušaj mogu obuhvatiti i radnje koje prethode radnji počinjenja tog kaznenog djela. ${ }^{24}$

\section{4. Počiniteljeva volja za dovršenjem djela kao subjektivni element pokušaja}

Odluka počinitelja da dovrši kazneno djelo obuhvaća svijest o svim okolnostima bića dotičnog kaznenog djela, kao i volju da počini kazneno djelo, odnosno, drugim riječima, podrazumijeva namjeru počinitelja i stoga se, da bismo mogli govoriti o pokušaju, mora raditi o namjeri počinitelja na dovršenje kaznenog djela. ${ }^{25}$ Namjera počinitelja da ostvari zakonska obilježja određenog kaznenog djela mora obuhvaćati njegovu svijest i htijenje da dovrši djelo, tako da nema namjere, posljedično niti pokušaja, ako kod njega nema odluke da počini djelo, bez obzira na to što je poduzeo neke radnje. ${ }^{26}$ Jednako tako, pokušaj će postojati u slučaju da počinitelj donese odluku o počinjenju djela, pod uvjetom da se ostvare odgovarajući uvjeti, jer takva situacija uključuje postojanje čvrste odluke. ${ }^{27}$ Za subjektivnu komponentu pokušaja, namjera ili dolus počinitelja nije dovoljna, posebice kod kaznenih djela sa subjektivnim obilježjima. Ta se obilježja kod pokušaja moraju ostvariti, primjerice, kod krađe to je namjera prisvajanja, a ukoliko počiniteljeva namjera ostane samo na ili u pokušaju, tada nema kaznene odgovornosti, jer njegova namjera mora ići za tim da dovrši djelo. ${ }^{28}$

\section{OPĆE PRAVILO O KAŽNJIVOSTI I KAŽNJAVANJU POKUŠAJA}

Temeljno pravilo o kažnjavanju i kažnjivosti pokušaja u hrvatskom kaznenom zakonodavstvu, sadržano je u odredbama čl. 34. KZ-a. Ujedno, u čl. 34., st. 1., al. 4. KZ-a, normirano je i pravno pravilo o posebnoj kažnjivosti pokušaja, kroz odrednicu ,ako zakon izričito propisuje kažnjavanje i za pokušaj“. Bivstveno, navedeno pravilo kao opće, upućuje na posebne odrednice, sadržane uz zakonske opise kaznenih djela u posebnom dijelu KZ-a, koje zapravo reguliraju posebne, iznimne slučajeve kažnjivosti pokušaja u hrvatskom kaznenom materijalnom pravu. „Kad se zakon odlučuje na kaznu za pokušaj kaznenog djela, polazi od ocjene da

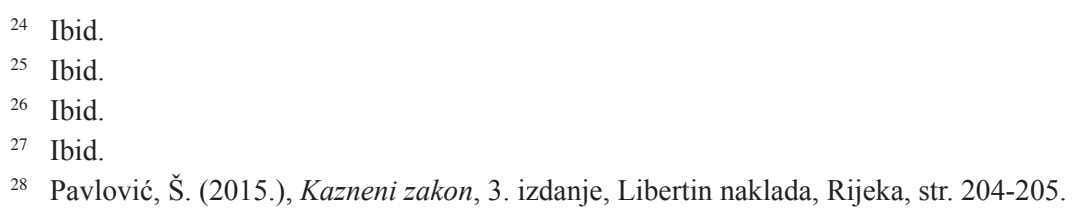


već samo započinjanje ostvarenja zakonskog bića djela zaslužuje kaznu i prije nego je došlo do povrede ili ugrožavanja.“" 29 „Pokušaj zaslužuje kaznu i zato što uvijek znači i napad na pravni poredak kao cjelinu. Osim što se manifestira kao napad na zaštićeno dobro, on je i napad na društveno proklamirane norme o zabranjenosti određenih ponašanja, važnih socijalnih normi. “" Glede kažnjavanja, treba istaknuti da je pokušaj zakonom predviđena fakultativna okolnost za ublažavanje kazne, ${ }^{31}$ sukladno odredbi čl. 34., st. 2. KZ-a. Dodatno, posebno široka ovlaštenja sud ima u slučaju nepodobnog pokušaja, ${ }^{32}$ kada sudi počinitelju koji je iz grube nerazumnosti ${ }^{33}$ pokušao počiniti kazneno djelo neprikladnim sredstvom ili prema neprikladnom objektu (čl. 34., st. 3. KZ-a), jer ga može u potpunosti osloboditi kazne. Sud prilikom odabira vrste i mjere kaznenopravne sankcije, odnosno odmjeravanja kazne, mora voditi računa o svim okolnostima slučaja, jednako kao kod dovršenog kaznenog djela, jer zakonska je odrednica da se počinitelj može ${ }^{34}$ blaže kazniti zbog pokušaja, ne da mora biti blaže kažnjen.

\section{NORMIRANOST POSEBNOG KAŽNJAVANJA POKUŠAJA U HRVATSKOM KAZNENOM ZAKONODAVSTVU}

U hrvatskom kaznenom zakonodavstvu propisano je 40 kaznenih djela u odnosu na koje je iznimno moguće počiniti pokušaj, izvan općeg pravila iz čl. 34. KZ-a. Od ukupno 26 glava koje u posebnom dijelu KZ-a normiraju kaznena djela, iznimno zakonsko propisivanje kažnjivosti pokušaja zastupljeno je u točno polovici glava KZ-a, konkretno u njih 13 ili 50 \%. Već u prvoj Glavi (IX.) KZ-a, u inkriminacijama protiv čovječnosti i ljudskog dostojanstva, nalazi se prvo kazneno djelo za koje je iznimno moguć pokušaj, a to je kazneno djelo trgovanja ljudima. Riječ je o jedinom takvom kaznenom djelu u navedenom dijelu KZ-a. Nadalje, iznimku kažnjavanja pokušaja nalazimo i u Glavi X. KZ-a, kod kaznenih djela protiv života i tijela, zatim, u Glavi XIII., kod kaznenih djela potiv osobne slobode, nadalje, u Glavi XVII. kod kaznenih djela spolnog zlostavljanja i iskorištavanja djeteta, Glavi XVIII., kaznena

29 Bačić - Pavlović, (2004.), ibid, str. 126.

30 Ibid, str. 127.

31 Prema: Bačić, F. (1980.), Krivično pravo - Opći dio, Informator, Zagreb, str. 312.

32 Ibid, str. 313.

33 Pavlović smatra da će ,mehaničko prevođenje njemačkog izraza Aus grobem Unverstand hrvatskim izrazom gruba nerazumnost u tumačenju i primjeni odredbe čl. 34., st. 3. KZ-a stvarati dvojbe i probleme“. Kao prikladniji izraz ističe pojmove ,gruba nemarnost“ ili „krajnja nepažnja“, kod koje pojedinac nije upotrijebio niti onu pažnju svojstvenu prosječnom čovjeku. Prema: Pavlović, Š. (2014.), Kazneni zakon, II. izmijenjeno, dopunjeno i prošireno izdanje, Libertin naklada, Rijeka, str. 63.

34 „Ukoliko egzistiraju takve otegotne okolnosti na strani optuženika zbog kojih se ne može primijeniti odredba o ublažavanju kazne, tada sud nije niti ovlašten optuženiku izreći najmanju moguću mjeru kazne temeljem tih odredbi.“ (VSRH broj: I Kž 658/12-6 od 2. listopada 2012.) 
djela protiv braka, obitelji i djece, Glavi XIX., kaznena djela protiv zdravlja ljudi, Glavi XX., kaznena djela protiv okoliša i u Glavi XXIII., kaznena djela protiv imovine. Jednako tako, barem po jednu inkriminaciju za koju je moguće iznimno kazniti pokušaj djela, nalazimo i kod kaznenih djela protiv računalnih sustava, programa i podataka (Glava XXV.), kaznenih djela krivotvorenja (Glava XXVI.), za kaznena djela protiv intelektualnog vlasništva (Glava XXVII.), za kaznena djela protiv javnog reda (Glava XXX.) i kod kaznenih djela protiv oružanih snaga Republike Hrvatske (Glava XXXIV.). Nijednog primjera iznimnog kažnjavanja pokušaja kaznenog djela nema među kaznenim djelima protiv ljudskih prava i temeljnih sloboda (Glava XI. KZ-a), kod kaznenih djela protiv radnih odnosa i socijalnog osiguranja (Glava XII. KZ-a), kaznenih djela protiv privatnosti (Glava XIV. KZ-a), u sklopu kaznenih djela protiv časti i ugleda (Glava XV.), kaznenih djela protiv spolne slobode (Glava XVI. KZ-a), opće sigurnosti (Glava XXI. KZ-a), protiv sigurnosti prometa (Glava XXII. KZ-a), kod kaznenih djela protiv gospodarstva (Glava XXIV. KZ-a), protiv službene dužnosti (Glava XXVIII. KZa) i protiv pravosuđa (Glava XXIX. KZ-a), kao ni u odnosu na kaznena djela protiv biračkog tijela (Glava XXXI. KZ-a), kaznena djela protiv Republike Hrvatske (Glava XXXII. KZ-a) te protiv strane države ili međunarodne organizacije (Glava XXXIII. KZ-a). U ukupnom broju propisanih kaznenih djela po glavama kaznenog zakonika, u njih 13 ili $50 \%$ nema predviđenog niti jednog kaznenog djela za koje se iznimno kažnjava pokušaj nekog kaznenog djela ili njegova pojavnog, najčešće kvalificiranog, oblika.

\section{KATALOG KAZNENIH DJELA ZA KOJE JE IZNIMNO KAŽNJIV POKUŠAJ}

\section{1. Kaznena djela protiv čovječnosti i ljudskog dostojanstva}

Poseban oblik kaznenog djela trgovanja ljudima u pokušaju iz čl. 106., st. 6. KZ-a u svezi sa st. 5. istoga članka KZ-a, postojat će i biti kažnjiv u slučaju da netko s ciljem omogućavanja počinjenja djela poduzme radnju u vidu zadržavanja, oduzimanja, sakrivanja, oštećenja ili uništenja putne isprave ili isprave o dokazivanju identiteta druge osobe, koja radnja prostorno i vremenski neposredno prethodi ostvarenju bića odnosnog kaznenog djela, u jednom od tri njegova pojavna oblika iz čl. 106., st. 1., 2. i 3. KZ-a. Propisana kazna za taj oblik djela inače iznosi do tri godine zatvora, slijedom čega ne može biti primijenjena općenita odredba o 
pokušaju, normirana čl. 34., st. 1. KZ-a, nego je navedeno protupravno ponašanje kažnjivo kao pokušaj na temelju isključive zakonske norme.

\section{2. Kaznena djela protiv života i tijela}

U odnosu na kazneno djelo protupravnog prekida trudnoće, kažnjiv je pokušaj osnovnog djela iz čl. 115., st. 1. KZ-a, na temelju odrednice st. 5. istoga članka KZa. Riječ je o namjernom poduzimanju radnje koja prostorno i vremenski prethodi radnji prekida trudnoće protivno propisima, ili izvršenja, poticanja ili pomoći pri prekidu trudnoće trudnoj osobi s njezinim pristankom. Za temeljni oblik kaznenog djela protupravnog prekida trudnoće zapriječena je kazna zatvora do tri godine. Svjedocima smo nastojanja da se pobačaj može obaviti u svakoj javnoj bolnici, unatoč prigovorima savjesti koje izražavaju liječnici, pa je za očekivati da broj slučajeva protupravnog prekida trudnoće, uključujući i pokušaj takvih kaznenih djela, neće biti isuviše velik.

\section{3. Kaznena djela protiv osobne slobode}

Sukladno odredbi čl. 136., st. 1. KZ-a, svatko „tko drugoga protupravno zatvori, drži zatvorena ili mu na drugi način oduzme ili ograniči slobodu kretanja“, ostvaruje zakonska obilježja kaznenog djela protupravnog oduzimanja slobode. Osnovni oblik kaznenog djela kažnjiv je kaznom zatvora do tri godine. Djelo će biti pokušano, a kažnjivo po čl. 136., st. 6. KZ-a, ukoliko bilo koja osoba poduzme određenu radnju koja prostorno i vremenski prethodi ostvarenju bića tog kaznenog djela, dakle, ukoliko pokuša nekoj drugoj osobi nezakonito oduzeti slobodu, odnosno ograničiti joj kretanje. U praksi bi moglo biti podosta prijeporno razgraničenje između pokušaja i dovršenog djela, s obzirom na činjenicu da je dovoljno i kraće vrijeme u kojemu je ograničeno kretanje žrtve za ostvarenje osnovnog oblika djela. Različiti su načini i modaliteti zatvaranja osoba i ograničavanja njihova kretanja, pa je prijeporno je li djelo pokušano ili dovršeno, primjerice, u situaciji kada počinitelj namami žrtvu u svoj automobil i odveze je nekoliko stotina metara, nakon čega ona uspije pobjeći.

\section{4. Kaznena djela spolnog zlostavljanja $i$ iskorištavanja djeteta}

Za pokušaj kaznenog djela zadovoljenja pohote pred djetetom mlađim od petnaest godina, u oba oblika, osnovnom iz čl. 160., st. 1. KZ-a i kvalificiranog iz čl. 160., st. 2., počinitelj će se kazniti, sukladno odredbi st. 3. istoga članka. 
Zapriječene kazne za oba oblika ovog kaznenog djela, a napomenimo da je riječ o spolnom zlostavljanju djece, vrlo su blage, do jedne, odnosno do tri godine. Opravdano je stoga normiranje iznimnog kažnjavanja pokušaja tih kaznenih djela, jer riječ je o pokušaju zadovoljavanja vlastite ili tuđe pohote pred djetetom mlađim od petnaest godina činjenjem spolnih radnji u tu svrhu (čl. 160., st. 1. KZ-a), odnosno nastojanju ostvarenja zakonskih obilježja kaznenih djela protiv spolne slobode ${ }^{35}$ pred djetetom mlađim od petnaest godina, što će se kazniti kaznom zatvora do tri godine. Predmetna kaznena djela, uključivo i pokušaji, karakteristični su za osobe romskog podrijetla, kao i u slučajevima osoba s nižim stupnjem intelektualnog razvoja, koje stupaju u spolne odnose s osobama starije životne dobi. U ovoj Glavi KZ-a imamo još jedno kazneno djelo, mamljenje djece za zadovoljenje spolnih potreba iz čl. 161., st. 1. KZ-a, za koje je iznimno pokušaj kažnjiv po odredbi st. 3. istoga članka KZ-a. Čini ga punoljetna osoba koja osobi mlađoj od petnaest godina, u namjeri da ona ili druga osoba nad njom počini kazneno djelo spolne zlouporabe djeteta mlađeg od petnaest godina iz čl. 158. KZ-a, putem informacijsko-komunikacijskih tehnologija ili na drugi način predloži susret s njom ili drugom osobom i koja poduzme mjere da do tog susreta dođe. Počinitelj će biti kažnjen kaznom zatvora do tri godine. Zbog neprestanog razvoja i napretka informacijsko-komunikacijskih tehnologija, olakšano je stupanje u kontakt sa svim građanima, uključivo i djecom, što može dovesti do neželjenih situacija poput predmetne, gdje se nastoji tim putem doprijeti do žrtve, s ciljem spolne zlouporabe djeteta.

\section{5. Kaznena djela protiv braka, obitelji i djece}

Pokušaj za kazneno djelo oduzimanja djeteta iz čl. 174., st. 2. kažnjiv je po odrednici st. 6. istoga članka KZ-a. Temeljno kazneno djelo čini roditelj ili posvojitelj koji dijete oduzme od (drugog) roditelja, (drugog) posvojitelja, skrbnika, druge osobe ili ustanove kojoj je ono povjereno, protupravno ga zadrži ili mu onemogućava da živi s osobom ili u ustanovi kojoj je povjereno (čl. 174., st. 1.). Počinitelja navedenog kaznenog djela može se kazniti kaznom zatvora do tri godine. Nisu rijetki slučajevi da nezadovoljni roditelji poduzmu protupravne radnje poput odvođenja djeteta od osobe kojoj je dijete povjereno na čuvanje i odgoj, zbog nezadovoljstva odlukom suda ili centra za socijalnu skrb. Opravdano je kažnjavanje pokušaja za kvalificirani oblik kaznenog djela oduzimanja djeteta, jer se odluke nadležnih tijela, donesene radi dobrobiti djeteta, moraju poštovati. Drugo kazneno djelo iz Glave XVIII. KZ-a, gdje je iznimno propisana kažnjivost pokušaja, jest promjena obiteljskog stanja (čl. 175. KZ-a). Pokušaj osnovnog

35 Izuzev kaznenog djela spolnog uznemiravanja iz čl. 156. KZ-a i kaznenog djela prostitucije iz čl. 157. KZ-a, u svim pojavnim oblicima. 
oblika predmetnog kaznenog djela promjene obiteljskog stanja kažnjiv je sukladno odredbi čl. 175., st. 3. KZ-a. Djelo čini onaj tko podmetanjem, zamjenom, davanjem lažnih podataka ili na drugi način promijeni obiteljsko stanje djeteta. Riječ je o relativno jednostavnom biću kaznenog djela, za sada ne tako čestom u hrvatskoj stvarnosti.

\section{6. Kaznena djela protiv zdravlja ljudi}

U odnosu na kazneno djelo krivotvorenja lijekova ili medicinskih proizvoda iz čl. 185. KZ-a, sukladno odredbi čl. 185., st. 6. KZ-a, predviđeno je kažnjavanje pokušaja za dva kvalificirana oblika tog kaznenog djela, iz čl. 185., stavka 3. i 4. KZ-a. „Tko izradi lažno ili preinači izvorno unutarnje ili vanjsko pakovanje lijeka ili medicinskog proizvoda, sažetak opisa svojstava lijeka, uputu o lijeku, uputu za uporabu medicinskog proizvoda, dokumentaciju o djelatnoj ili pomoćnoj tvari, kaznit će se kaznom zatvora do tri godine (čl. 185., st. 3. KZ-a)“. „Kaznom iz stavka 3. ovoga članka kaznit će se tko upotrijebi izvorno unutarnje ili vanjsko pakovanje lijeka ili medicinskog proizvoda, sažetak opisa svojstava lijeka, uputu o lijeku, uputu za uporabu medicinskog proizvoda, dokumentaciju o djelatnoj ili pomoćnoj tvari, izvan onoga za što su bili namijenjeni u legalnom snabdjevnom lancu lijekova i medicinskih proizvoda (čl. 185. st. 4. KZ)“. Namjerno poduzimanje radnji koje vremenski i prostorno prethode ostvarenju zakonskih obilježja navedena dva oblika kaznenog djela krivotvorenja lijekova ili medicinskih proizvoda, kažnjivo je kaznom zatvora do tri godine.

\section{7. Kaznena djela protiv okoliša}

Kod kaznenih djela protiv okoliša, pokušaj je kažnjiv za kazneno djelo promjene vodnog režima, u odnosu na temeljni oblik djela iz čl. 210., st. 1. KZ-a, koje čini onaj tko protivno propisima promijeni ili poremeti vodni režim, a time ne čini neko drugo kazneno djelo za koje je propisana teža kazna. Za osnovni oblik djela, uključivo i pokušaj osnovnog oblika, predviđena je kazna zatvora do dvije godine. Pokušaj je kažnjiv prema odrednici čl. 210., st. 4. KZ-a, jednako kao i za kvalificirani oblik, koji ostvaruje tko osnovni oblik kaznenog djela promjene vodnog režima počini na području koje je propisom ili odlukom nadležnog tijela proglašeno zaštićenom prirodnom vrijednosti. Za navedeni teži oblik istog kaznenog djela, kao i za pokušaj, počinitelj ce se kazniti kaznom zatvora do tri godine. Sukladno odredbi čl. 211., st. 4. KZ-a, kažnjiv je posebno i pokušaj kaznenog djela protupravne eksploatacije rudnog blaga, odnosno njegov osnovni oblik, koji će počiniti onaj 
tko protivno propisima obavlja eksploataciju rudnog blaga i time prouzroči znatnu štetu. Zapriječena je kazna zatvora do tri godine.

\section{8. Kaznena djela protiv imovine}

Kod imovinskih delikata, iznimno kažnjavanje pokušaja propisano je kod kaznenog djela oduzimanja tuđe pokretne stvari. Pokušaj kvalificiranog oblika kaznenog djela oduzimanja tuđe pokretne stvari (čl. 234., st. 2. KZ-a) posebno je kažnjiv temeljem odredbe čl. 234., st. 3. KZ-a, a čini ga svatko tko neovlašteno oduzme tuđe motorno vozilo radi privremene uporabe. Predviđena je kazna zatvora do tri godine za počinitelja kaznenog djela oduzimanja tuđe pokretne stvari u pokušaju iz čl. 243., st. 3. u svezi sa st. 2. istoga članka KZ-a. „Okrivljenik je bez znanja vlasnika ušao u njegov osobni automobil, pokrenuo vozilo rezervnim ključem koji je dobio od vlasnika te sa parkirnog mjesta krenuo unatrag i sa zadnjim dijelom vozila udario u zid stambene zgrade, nakon čega je navedeni automobil vratio na mjesto gdje je bio parkiran, čime je počinio kazneno djelo neovlaštene uporabe tuđe pokretne stvari u pokušaju, opisano u čl. 234., st. 3. u svezi sa st. 2. istoga članka KZ/11." ${ }^{36}$ Novelom KZ-a, ${ }^{37}$ konkretno od 30. svibnja 2015. godine, uvedeno je iznimno kažnjavanje pokušaja kaznenog djela krađe, sukladno odredbi noveliranog čl. 228., st. 5. KZ-a. Navedena korekcija zakonskog teksta učinjena je iz razloga što je snižena kazna za osnovno kazneno djelo krađe iz čl. 228., st. 1. KZ-a, na maksimalno tri godine zavora, za razliku od prijašnje propisane kazne od 6 mjeseci do 5 godina zatvora, uslijed čega više nije moguća primjena opće odrednice o kažnjavanju pokušaja iz čl. 34., st. 1. KZ-a.

\subsection{Kaznena djela protiv gospodarstva}

U Glavi XXIV. KZ-a, normirano je jedno kazneno djelo kod kojega je iznimno kažnjiv pokušaj, neovlaštena uporaba tuđe tvrtke. Zakonska obilježja kaznenog djela ostvaruje svatko tko neovlašteno uporabi tuđu tvrtku ili u nju unese obilježja koja stvaraju zabunu glede predmeta poslovanja trgovačkog društva, identiteta ili povezanosti s drugim društvom i na taj način pribavi imovinsku korist ili prouzroči štetu. Za pokušaj jedinog oblika ovog kaznenog djela, počinitelj će biti kažnjen prema odrednici čl. 261., st. 2. KZ-a.

\footnotetext{
36 OsVt broj: $6 \mathrm{~K}-288 / 14-2$ od 19. studenoga 2014.

37 NN 56/15 od 22. svibnja 2015.
} 


\section{10. Kaznena djela protiv računalnih sustava, programa i podataka}

U okviru Glave XXV. KZ-a, kaznena djela protiv računalnih sustava, programa i podataka, kao prvo djelo normirano je kazneno djelo neovlaštenog pristupa. Uz činjenicu da sam naziv kaznenog djela bespotrebno stvara pravnu nesigurnost zbog nedorečenosti, jer bilo koji primjenjivač, ukoliko mu nije poznat ili predočen puni naziv cijele glave općeg materijalnog kaznenog zakonika, neće znati o kojem kaznenom djelu je uopće riječ, niti koji je zaštitni objekt kod ovog kaznenog djela. Osnovni oblik djela neovlaštenog pristupa, sukladno čl. 266., st. 1. KZ-a, čini svatko tko neovlašteno pristupi računalnom sustavu ili računalnim podacima, za što je predviđena kazna zatvora u trajanju do jedne godine. Pokušaj je kažnjiv prema odredbi čl. 266., st. 3. u svezi sa st. 1. istoga članka KZ-a, jednako kao i za kvalificirani oblik iz čl. 266., st. 2. KZ-a, koji čini onaj tko neovlašteno pristupi računalnom sustavu ili računalnim podacima u odnosu na računalni sustav ili računalne podatke tijela državne vlasti, tijela jedinica lokalne ili područne (regionalne) samouprave, javne ustanove ili trgovačkog društva od posebnog javnog interesa. Kazna je za kvalificirani oblik, naravno, stroža, do tri godine zatvora. Pokušaj kvalificiranog oblika kaznenog djela neovlaštenog pristupa kažnjiv je temeljem čl. 266., st. 3 . u svezi sa st. 2. istoga članka KZ-a. Zanimljivo je istaknuti da se kazneni progon za osnovni oblik kaznenog djela neovlaštenog pristupa progoni po prijedlogu oštećenika, a ipak se zakonodavac odlučio za posebno kažnjavanje pokušaja i za taj, temeljni oblik djela. Sljedeće kazneno djelo iz ove glave za koje je kažnjiv pokušaj jest ometanje rada računalnog sustava. Tko onemogući ili oteža rad ili korištenje računalnog sustava, računalnih podataka ili programa ili računalnu komunikaciju, kaznit će se kaznom zatvora do tri godine (čl. 267., st. 1. KZ-a). Pokušaj jedinog oblika ovog kaznenog djela kažnjiv je po odredbi st. 2. istoga članka KZ-a. Kažnjiv je i pokušaj oštećenja računalnih sustava, zakonska obilježja kojeg kaznenog djela ostvaruje počinitelj koji neovlašteno u cijelosti ili djelomično ošteti, izmijeni, izbriše, uništi, učini neuporabljivim ili nedostupnim ili prikaže nedostupnim tuđe računalne podatke ili programe, a kaznit će se kaznom zatvora do tri godine (čl. 268., st. 1. KZ-a). Pokušaj jedinog oblika ovog kaznenog djela kažnjiv je po odredbi st. 2. istoga članka KZ-a. Neovlašteno presretanje računalnih podataka čini tko neovlašteno presretne ili snimi nejavni prijenos računalnih podataka, uključujući i elektromagnetsku emisiju računalnog sustava, ili drugome učini dostupnim tako pribavljene podatke, kaznit će se kaznom zatvora do tri godine (čl. 269., st. 1. KZa). Pokušaj jedinog oblika ovog kaznenog djela kažnjiv je po odredbi st. 2. istoga članka KZ-a. Posljednje kazneno djelo na koje je propisana kažnjivost pokušaja jest računalno krivotvorenje. Osnovni oblik djela počinit će tko neovlašteno izradi, unese, izmijeni, izbriše ili učini neuporabljivim ili nedostupnim računalne 
podatke koji imaju vrijednost za pravne odnose, u namjeri da se oni uporabe kao vjerodostojni, ili tko takve podatke uporabi ili nabavi radi uporabe, kaznit će se kaznom zatvora do tri godine (čl. 270., st. 1. KZ-a). Pokušaj kaznenog djela iz računalnog krivotvorenja iz čl. 270., st. 1. kažnjiv je sukladno odredbi čl. 270., st. 2. KZ-a. Razvidno je kako kod tzv. računalnog kriminaliteta imamo predviđenu kažnjivost pokušaja za ukupno pet kaznenih djela, sa sveukupno šest modaliteta, od čega samo jedan slučaj propisane kažnjivosti pokušaja kvalificiranog oblika djela, konkretno neovlaštenog pristupa iz čl. 266., st. 2. KZ-a. Ne nalazimo posebnu opravdanost činjenice normiranja tako velikog broja iznimnog kažnjavanja pokušaja, s obzirom na činjenicu relativno malog udjela navedenih kaznenih djela u ukupnom kriminalitetu, kao i zapriječene kazne za predmetna kaznena djela po zakonodavcu, uz dodatno uvažavanje okolnosti da se u pretežnom broju slučajeva radi o samo jednom, osnovnom obliku djela.

\section{11. Kaznena djela krivotvorenja}

Drugom novelom KZ-a ${ }^{38}$ normirana je kažnjivost pokušaja kaznenog djela krivotvorenja novca iz čl. 274., st. 3. u svezi sa st. 2. istoga članka KZ-a, na način da je propisano da će biti kažnjen za pokušaj onaj tko lažni novac koji je primio u uvjerenju da je pravi, saznavši da je lažan, stavi u optjecaj. Za navedeni oblik kaznenog djela iz čl. 274., st. 2. KZ-a inače je zapriječena kazna zatvora do tri godine. Država se i inače uobičajeno pojačano gleda zaštititi od slučajeva krivotvorenja novca, stoga ne čudi niti ovo noveliranje do tada važećeg zakonskog teksta materijalnog kaznenog zakonika, prije se moguće izraziti čuđenje zašto se tome nije priklonilo odmah, prilikom izvorne redakcije teksta KZ-a. ${ }^{39}$ Suprotno slučajevima tzv. računalnog kriminaliteta, krivotvorenja su daleko češća, učestalija kaznena djela u praksi, stoga je posve opravdano propisati i izuzetke od opće kažnjivosti pokušaja, naročito kod kaznenog djela krivotvorenja isprave. Osnovni oblik tog djela čini tko izradi lažnu ispravu ili preinači pravu s ciljem da se takva isprava uporabi kao prava ili tko takvu ispravu nabavi radi uporabe ili je uporabi kao pravu (čl. 278., st. 1. KZ-a). Počinitelj će se kazniti kaznom zatvora do tri godine. Istom kaznom kaznit cee se tko obmane drugoga o sadržaju kakve isprave $i$ ovaj stavi svoj potpis na tu ispravu, držeći da se potpisuje pod kakvu drugu ispravu

38 NN 56/15. od 22. svibnja 2015.

39 Iz Obrazloženja Konačnog prijedloga Zakona o izmjenama i dopunama Kaznenog zakona (u daljnjem tekstu: Obrazloženje), proizlazi da je novela i iznimno kažnjavanje pokušaja za kazneno djelo iz čl. 274., st. 2. KZ-a, izvršeno radi usklađenja hrvatskog kaznenog zakonodavstva s Direktivom 2014/62/EU od 15. svibnja 2014. o kaznenopravnoj zaštiti eura i drugih valuta od krivotvorenja, kojom se zamjenjuje Okvirna odluka Vijeća 2000/383/PUP. Prema: Obrazloženje, str. 48. Dostupno na: http://www. sabor.hr/konacni-prijedlog-zakona-o-izmjenama-i-dopunama-ka (pristupljeno: 27. 5. 2015.). 
ili pod kakav drugi sadržaj, ostvarujući time kvalificirani oblik istog kaznenog djela iz čl. 278., st. 2. KZ-a. Iznimno, posebno kažnjavanje pokušaja predviđeno je za pokušaj osnovnog, ali i kvalificiranog oblika kaznenog djela krivotvorenja isprave, prema čl. 278., st. 4. KZ-a.

\section{12. Kaznena djela protiv intelektualnog vlasništva}

Kod kaznenih djela protiv intelektualnog vlasništva imamo čak 9 pojavnih oblika četiri kaznenih djela za koja je normirana zakonskim putem kažnjivost pokušaja, unatoč zapriječenim kaznama. U odnosu na kazneno djelo nedozvoljene uporabe autorskog djela ili izvedbe umjetnika izvođača iz čl. 285. KZ-a, normirana je posebna kažnjivost pokušaja za čak tri oblika tog djela, sukladno odredbi čl. 285., st. 4. u svezi sa st. 1. istoga članka KZ-a (osnovni oblik djela), koji čini onaj tko protivno propisima kojima se uređuju autorsko i srodna prava reproducira, preradi, distribuira, skladišti ili poduzima druge radnje radi distribucije ili priopći javnosti na bilo koji način tuđe autorsko djelo ili dopusti da se to učini i na taj način pribavi znatnu imovinsku korist ili prouzroči znatnu štetu; zatim, prema odredbi čl. 285., st. 4. u svezi sa st. 2. istoga članka KZ-a (kvalificirani oblik), koji čini tko protivno propisima kojima se uređuje autorsko i srodna prava fiksira tuđu nefiksiranu izvedbu umjetnika izvođača, reproducira, preradi, distribuira, skladišti ili poduzima druge radnje radi distribucije tuđe fiksirane izvedbe umjetnika izvođača ili priopći javnosti na bilo koji način tuđu fiksiranu ili nefiksiranu izvedbu umjetnika izvođača ili dopusti da se to učini i na taj način pribavi znatnu imovinsku korist ili prouzroči znatnu štetu; i naposljetku, prema odrednici čl. 285., st. 4. u svezi sa st. 3. istoga članka KZ-a (kvalificirani oblik), koji će počiniti svatko tko protivno propisima kojima se uređuju autorsko i srodna prava osujećuje tehničke mjere za zaštitu prava autora i umjetnika izvođača ili ukloni ili preinači podatke o upravljanju tim pravima i na taj način pribavi znatnu imovinsku korist ili prouzroči znatnu štetu. Za sve navedene oblike kaznenog djela nedozvoljene uporabe autorskog djela ili izvedbe umjetnika izvođača zapriječena je istovjetna kazna, kazna zatvora do tri godine. Još brojniji slučajevi posebne kažnjivosti pokušaja predviđeni su za kazneno djelo povrede drugih autorskom srodnih prava iz čl. 286. KZ-a, gdje je predviđena kažnjivost pokušaja za čak četiri oblika tog kaznenog djela. Osnovni oblik čini tko protivno propisima kojima se uređuju autorsko i srodna prava reproducira, distribuira, skladišti ili poduzima druge radnje radi distribucije, ili stavi na raspolaganje javnosti tuđi fonogram ili dopusti da se to učini i na taj način pribavi znatnu imovinsku korist ili prouzroči znatnu štetu, a kaznit će se kaznom zatvora do jedne godine (čl. 286., st. 1. KZ-a). Pokušaj je kažnjiv, kao i za sve kvalificirane oblike iz st. 2., st. 3. i st. 4. čl. 286. KZ-a prema čl. 286., st. 5. KZ-a. Kvalificirani 
oblik djela iz čl. 286., st. 2. KZ-a čini tko protivno propisima kojima se uređuju autorsko i srodna prava reproducira, distribuira, skladišti ili poduzima druge radnje radi distribucije, ili javno prikaže ili stavi na raspolaganje javnosti tuđi videogram ili dopusti da se to učini i na taj način pribavi znatnu imovinsku korist ili prouzroči znatnu štetu. Jednako tako, obilježja kvalificiranog oblika kaznenog djela povrede drugih autorskom srodnih prava čini i svatko tko protivno propisima kojima se uređuju autorsko i srodna prava reemitira tuđe emitiranje, ili javno priopći tuđe emitiranje uz plaćanje ulaznica ili stavi na raspolaganje javnosti tuđe emitiranje ili dopusti da se to učini i na taj način pribavi znatnu imovinsku korist ili prouzroči znatnu štetu (čl. 286., st. 3. KZ-a). U konačnici, kaznit će se tko protivno propisima kojima se uređuju autorsko i srodna prava osujećuje tehničke mjere za zaštitu srodnih prava proizvođača fonograma, videograma ili organizacija za radiodifuziju ili ukloni ili preinači podatke o upravljanju tim pravima ili dopusti da se to učini i na taj način pribavi znatnu imovinsku korist ili prouzroči znatnu štetu (čl. 286., st. 4. KZ-a), kao posljednji normirani modalitet ovog kaznenog djela, za koje je istovremeno kažnjiv i pokušaj. Posebnost kod ovog slučaja iznimne kažnjivosti pokušaja jest vrlo blaga kazna, do jedne godine zatvora, što ukazuje na to da je riječ o bagatelnim kaznenim djelima. Slijedom navedenoga, nema posebnog razloga za normiranje, poglavito ne u tolikom broju slučajeva i modaliteta, kažnjivosti pokušaja kaznenog djela povrede drugih autorskom srodnih prava. Povreda prava na izum predstavlja kazneno djelo koje čini onaj tko protivno propisima o zaštiti patenta izrađuje, nudi na prodaju, prodaje, rabi, izvozi, uvozi ili skladišti u te svrhe proizvod izrađen prema izumu koji je zaštićen patentom ili svjedodžbom o dodatnoj zaštiti ili primjenjuje ili nudi primjenu postupka koji je predmet zaštićenog izuma ili nudi na prodaju, prodaje, rabi, izvozi, uvozi ili skladišti u te svrhe proizvod koji je izravno dobiven postupkom koji je predmet izuma i na taj način pribavi znatnu imovinsku korist ili prouzroči znatnu štetu, a kaznit će se kaznom zatvora do tri godine (čl. 287., st. 2. KZ-a). Na temelju odredbe čl. 287., st. 3. KZ-a, kažnjiv je pokušaj odnosnog kvalificiranog oblika kaznenog djela povrede prava na izum iz čl. 287., st. 2. KZ-a. Povreda žiga je sljedeće kazneno djelo za koje je propisana kažnjivost pokušaja. Osnovni oblik djela čini tko protivno propisima o zaštiti žiga u trgovačkom prometu rabi znak koji je istovjetan sa zaštićenim žigom u odnosu na proizvode ili usluge koje su istovjetne s onima za koje je žig registriran ili znak koji je istovjetan ili sličan zaštićenom žigu u odnosu na proizvode ili usluge koji su istovjetni ili slični s onima za koje je žig registriran, ističući znak na proizvodima ili njihovim pakiranjima, nudeći ili stavljajući na tržište ili skladišteći u te svrhe proizvod pod tim znakom ili nudeći ili pružajući usluge pod tim znakom ili uvozeći ili izvozeći proizvode obilježene tim znakom ili rabeći znak na poslovnim proizvodima i u reklamiranju, čime javnost može biti dovedena u zabludu o 
podrijetlu proizvoda i usluga, i na taj način pribavi znatnu imovinsku korist ili prouzroči znatnu štetu (čl. 288., st. 1. KZ-a). Pokušaj kaznenog djela povrede žiga iz čl. 288., st. 1. KZ-a, kažnjava se sukladno odredbi st. 2. istoga članka KZ-a. Za osnovno djelo, a do navedene gornje granice je moguće počinitelja kazniti i zbog pokušaja djela, zapriječena je zatvorska kazna do tri godine.

\section{13. Kaznena djela protiv javnog reda}

Iznimno brojni su slučajevi propisivanja kažnjivosti pokušaja kod kaznenih djela protiv javnog reda i mira, što je objašnjivo činjenicom da je prilikom donošenja novog kaznenog zakona, u predmetna kaznena djela uvršten i odgovarajući broj kaznenih djela koja su ranije pripadala drugim vrstama kaznenih djela. Tako je poduzimanje radnji koje vremenski i prostorno prethode ostvarenju bića kaznenog djela skidanja i povrede službenog pečata i znaka, kažnjivo je po čl. 317., st. 2. u svezi sa st. 1. istoga članka KZ-a. Temeljni oblik djela ostvaruje onaj tko skine ili povrijedi službeni pečat ili znak koji je ovlaštena službena osoba stavila radi osiguranja predmeta, prostorije ili prostora, ili tko bez skidanja ili povrede pečata ili znaka uđe u takav prostor ili prostoriju ili otvori osigurani predmet, kaznit će se kaznom zatvora do tri godine (čl. 317., st. 1. KZ-a). Pokušaj osnovnog oblika kaznenog djela oduzimanja ili uništenja službenog pečata ili službenog spisa kažnjiv je po odredbi čl. 318., st. 3. KZ-a. Počinitelj će biti onaj tko s namjerom započne protupravno oduzimaje, skrivanje, uništenje, oštećenje ili na drugi način učini neuporabljivim službeni pečat, knjigu, spis ili ispravu. Zapriječena je kazna zatvora do tri godine, sukladno odredbi čl. 318., st. 1. KZ-a. Oštećenje i nedozvoljeni izvoz kulturnog dobra u pokušaju, kažnjivo je sukladno odredbi čl. 319., st. 4. KZ-a, u odnosu na osnovni i kvalificirani oblik djela. Temeljni oblik iz čl. 319., st. 1. KZ-a čini tko ošteti ili uništi kulturno dobro, za što će se kazniti kaznom zatvora do tri godine. Istom kaznom kaznit će se tko bez odobrenja nadležnog tijela trajno izveze ili iznese iz Republike Hrvatske kulturno dobro ili ga ne vrati u Republiku Hrvatsku u roku određenom odobrenjem (čl. 319., st. 2. KZ-a), što je kvalificirani oblik tog kaznenog djela, za koji je također iznimno propisana kažnjivost pokušaja. Javno poticanje na nasilje i mržnju u osnovnom obliku čini tko putem tiska, radija, televizije, računalnog sustava ili mrě̌e, na javnom skupu ili na drugi način javno potiče ili javnosti učini dostupnim letke, slike ili druge materijale kojima se poziva na nasilje ili mržnju usmjerenu prema skupini ljudi ili pripadniku skupine zbog njihove rasne, vjerske, nacionalne ili etničke pripadnosti, podrijetla, boje kože, spola, spolnog opredjeljenja, rodnog identiteta, invaliditeta ili kakvih drugih osobina, kaznit će se kaznom zatvora do tri godine (čl. 325., st. 1. KZ-a). Istovjetnom kaznom kao za navedeni osnovni oblik djela, kaznit će se 
tko javno odobrava, poriče ili znatno umanjuje kazneno djelo genocida, zločina agresije, zločina protiv čovječnosti ili ratnog zločina, usmjereno prema skupini ljudi ili pripadniku skupine zbog njihove rasne, vjerske, nacionalne ili etničke pripadnosti, podrijetla ili boje kože, na način koji je prikladan potaknuti nasilje ili mržnju protiv takve skupine ili pripadnika te skupine (čl. 325., st. 4. u svezi sa st. 1. istoga članka KZ-a). Pokušaj temeljnog oblika i kvalificiranog oblika predmetnog kaznenog djela javnog poticanja na nasilje i mržnju, kažnjiv je prema odredbi čl. 325., st. 5. KZ-a. Za pokušaj kvalificiranog oblika kaznenog djela povrede mira pokojnika iz čl. 332., st. 2. KZ-a, počinitelj će biti kažnjen prema odrednici čl. 332., st. 3. KZ-a. Djelo čini onaj tko poduzme radnje koje prostorno i vremenski prethodne radnjama neovlaštenog iskopa, odnošenja, oštećenja, uništenja, skrivanja ili premještanja tijela, fetusa, dijela tijela ili pepela umrle osobe, ili radnji oskvrnuća tijela pokojnika. Za osnovni oblik kaznenog djela, sukladno tome i za pokušaj, počinitelj će se kazniti kaznom zatvora do dvije godine.

\section{14. Kaznena djela protiv oružanih snaga Republike Hrvatske}

Vojna osoba koja u obavljanju dužnosti ne podnese izvješće ili u izvješću prešuti neku činjenicu koju ne bi smjela prešutjeti ili podnese izvješće neistinitog sadržaja pa time ugrozi službu, kaznit će se kaznom zatvora do tri godine (čl. 364., st. 1. KZ-a). Pokušaj kaznenog djela podnošenja neistinih izvješća i neizvješćivanja je kažnjiv sukladno odrednici st. 4. istoga članka KZ-a. To je jedino kazneno djelo protiv oružanih snaga u odnosu na koje je iznimno propisana kažnjivost pokušaja.

\section{IZVORNO PROPISANE KAZNE KOJE UTJEČU NA NEPRIMJENU PRAVILA O TEMELJNOM KAŽNJAVANJU POKUŠAJA PREMA ČL. 34. KZ-A}

U odnosu na dva kaznena djela, odnosno svega $5 \%$ kaznenih djela za koja je previđeno iznimno kažnjavanje pokušaja, predviđena je kazna zatvora u trajanju do dvije godine. Riječ je o kaznenom djelu promjene vodnog režima u pokušaju iz čl. 210., st. 4. u svezi sa st. 1. istoga članka KZ-a i kaznenom djelu povrede mira pokojnika u pokušaju iz čl. 332., st. 3. u svezi sa st. 2. istoga članka KZ-a. Za ukupno tri kaznena djela, konkretno kazneno djelo zadovoljenja pohote pred djetetom mlađim od petnaest godina u pokušaju iz čl. 160., st. 3. u svezi sa st. 1. istoga članka KZ-a, kazneno djelo neovlaštenog pristupa u pokušaju iz čl. 266., st. 3. u svezi sa st. 1. istoga članka KZ-a i kazneno djelo povrede drugih autorskom srodnih prava u pokušaju iz čl. 286., st. 5. u svezi sa st. 1. istoga članka KZ-a, 
propisana je izrazito blaga kazna zatvora do jedne godine. Opravdanost posebne kažnjivosti pokušaja za odnosna kaznena djela, koja ulaze prema zapriječenim kaznama u kategoriju bagatelnog kriminaliteta, doista je upitna i nameće se pitanje krajnjeg cilja ili svrhe njihove posebne kažnjivosti. U ukupnom postotku kaznenih djela za koja temeljni zakon kaznenog materijalnog prava posebno normira kažnjavanje i kažnjivost pokušaja, to iznosi 7,5 \%. Prevladavajuća kazna kod kaznenih djela za koja je predviđena posebna mogućnost, izvan općeg pravila kažnjavanja pokušaja, jest kazna zatvora u trajanju do tri godine, koja se pojavljuje kod 35 kaznenih djela, odnosno pojavnih oblika kaznenih djela. Dakle, u ukupno 87,5 \% slučajeva, zakonom je predviđena mogućnost iznimnog kažnjavanja pokušaja kod kaznenih djela sa zapriječenom kaznom zatvora do tri godine. Vidljivo je kako se zakonodavac prilikom normiranja iznimnih slučajeva kažnjavanja pokušaja pojedinih kaznenih djela, odlučio u prevladavajućoj mjeri za teže oblike određenih kaznenih djela, koja nominalno u osnovnom obliku ne predstavljaju posebnu društvenu opasnost i ulaze u kategoriju lakših kaznenih djela, ali koja opet, s druge strane, u određenim okolnostima, potražuju kaznenopravnu zaštitu i u slučaju pokušaja. Nastavno, za sva kaznena djela za koja je predviđena zakonskim putem mogućnost posebnog kažnjavanja, izvan općeg pravila o kažnjivosti, pokušaja, moguće je izreći počiniteljima i novčanu kaznu, kao glavnu kaznu, sukladno odredbi čl. 40., st. 4. KZ-a. Potonje podrazumijeva mogućnost primjene novčane kazne kao alternativne sankcije zatvoru, primarno propisanoj kaznenoj sankciji za navedena protupravna ponašanja. Uređujući sudac tako ima na raspolaganju dodatnu mogućnost individualizacije kaznenopravne sankcije za pokušaj, nedovršeno, a započeto kazneno djelo, koje iziskuje društvenu reakciju zbog opasnosti počinitelja i djela.

\section{ZAKLJUČAK}

U hrvatskom kaznenom zakonodavstvu izuzetno, ali ne i mnogo rjeđe od općeg pravila, normirana je kažnjivost pokušaja u odgovarajućim slučajevima, nevezano uz zapriječenu kaznu za određeno kazneno djelo. Opće pravilo kažnjivosti pokušaja normirano je odrednicom čl. 34., st. 1. KZ-a, uz poveznicu s relevantnom odrednicom pojedinog kaznenog djela iz posebnog dijela kaznenog materijalnog zakona. Zakonodavac se takvim rješenjem odlučio za iznimno kažnjavanje pokušaja neovisno o činjenici da je riječ o lakšem kaznenom djelu, sudeći po propisanoj kazni za počinjenje i počinitelja. U čl. 34., st. 1., al. 4. KZ-a, normirano je i pravno pravilo o posebnoj kažnjivosti pokušaja, kroz odrednicu ,ako zakon izričito propisuje kažnjavanje i za pokušaj“. 
Naše kazneno zakonodavstvo sadrži 42 kaznena djela u odnosu na koje je iznimno moguće počiniti pokušaj, a od ukupno 26 glava koje u posebnom dijelu KZ-a normiraju kaznena djela, iznimno zakonsko propisivanje kažnjivosti pokušaja zastupljeno je u točno polovici, konkretno u njih 13 ili 50 posto. Nijednog primjera iznimnog kažnjavanja pokušaja kaznenog djela nema među kaznenim djelima protiv ljudskih prava i temeljnih sloboda, kod kaznenih djela protiv radnih odnosa i socijalnog osiguranja, kaznenih djela protiv privatnosti, u sklopu kaznenih djela protiv časti i ugleda, kaznenih djela protiv spolne slobode, opće sigurnosti, protiv sigurnosti prometa, kod kaznenih djela protiv gospodarstva, protiv službene dužnosti i protiv pravosuđa, kao ni u odnosu na kaznena djela protiv biračkog tijela, kaznenih djela protiv Republike Hrvatske te protiv strane države ili međunarodne organizacije. U većini slučajeva, po pojedinom dijelu ili glavi KZ-a nalazimo po jedno ili dva kaznena djela s posebnim kažnjavanjem pokušaja, a primjerice kod tzv. računalnog kriminaliteta imamo predviđenu kažnjivost pokušaja za ukupno pet kaznenih djela, sa sveukupno šest modaliteta, od čega samo jedan slučaj propisane kažnjivosti pokušaja kvalificiranog oblika djela, konkretno neovlaštenog pristupa iz čl. 266., st. 2. KZ-a. Ne nalazimo posebnu opravdanost činjenice normiranja tako velikog broja iznimnog kažnjavanja pokušaja, s obzirom na činjenicu relativno malog udjela navedenih kaznenih djela u ukupnom kriminalitetu, kao i zapriječene kazne za predmetna kaznena djela po zakonodavcu, uz dodatno uvažavanje okolnosti da se u pretežnom broju slučajeva radi o samo jednom, osnovnom obliku djela. Više slučajeva iznimne kažnjivosti pokušaja pronalazimo i kod kaznenih djela protiv javnog reda i mira, što je objašnjivo činjenicom da je prilikom donošenja novog kaznenog zakona, u predmetna kaznena djela uvršten i odgovarajući broj kaznenih djela koja su ranije pripadala drugim vrstama kaznenih djela. Začuđuje da je najveći broj posebnih slučajeva kažnjivosti pokušaja normiran kod kaznenih djela protiv intelektualnog vlasništva, gdje imamo čak devet pojavnih oblika četiri kaznenih djela za koja je normirana zakonskim putem kažnjivost pokušaja, što je gotovo neobjašnjivo.

Zakonom je predviđena mogućnost iznimnog kažnjavanja pokušaja kod kaznenih djela sa zapriječenom kaznom zatvora do tri godine u ukupno 88,1\% slučajeva, dok se preostali postotak odnosi na kaznena djela s propisanom kaznom zatvora do dvije godine $(4,76 \%)$, odnosno čak do jedne godine zatvora $(7,14 \%)$, gdje potonja ulaze u kategoriju bagatelnog kriminaliteta i isto takvih kaznenih djela. Zanimljivo je sagledati i primijetiti da se zakonodavac i kod takvih kaznenih djela odlučio za zakonsku mogućnost posebne, iznimne kažnjivosti pokušaja. Za pretpostaviti je kako je upravo takvo rješenje rezultat svijesti o opasnosti kaznenog djela i opasnosti počinitelja za zaštićeno pravno dobro i sustav u cjelini, što nastavno opravdava dotično zakonsko rješenje. 


\section{POPIS LITERATURE:}

1. Bačić, F. (1980.), Krivično pravo - Opći dio, Informator, Zagreb.

2. Bačić, F. (1995.), Krivično pravo - opći dio, Informator, Zagreb.

3. Bačić, F. - Šeparović, Z. (1997.), Krivično pravo - posebni dio, Informator, Zagreb.

4. Bačić, F. - Pavlović, Š. (2004.), Komentar Kaznenog zakona, Organizator, Zagreb.

5. Horvatić, Ž. (1997.), Novo hrvatsko kazneno pravo, Organizator, Zagreb.

6. Horvatić, Ž. (1997.), Rječnik kaznenog prava, Masmedia, Zagreb.

7. Novoselec, P., „Razgraničenje pripremnih radnji i pokušaja“, Zbornik Pravnog fakulteta Sveučilišta u Rijeci (1991.), v. 29, br. 2.

8. Novoselec, P. (2004.), Opći dio kaznenog prava, Sveučilište u Zagrebu, Zagreb.

9. Pavlović, Š., „Razgraničenje pripremnih radnji i pokušaja prema novom Kaznenom zakonu“, Hrvatski ljetopis za kazneno pravo i praksu (Zagreb), vol. 19, broj 2/2012.

10. Pavlović, Š. (2014.), Kazneni zakon, II. izmijenjeno, dopunjeno i prošireno izdanje, Libertin naklada, Rijeka.

11. Pavlović, Š. (2015.), Kazneni zakon, 3. izdanje, Libertin naklada, Rijeka. 


\section{PARTICULAR LEGAL REGULATION OF THE PUNISHABILITY OF ATTEMPT}

The general rule on the punishment and culpability attempted criminal offense is separately regulated under the substantive criminal code, which prescribes the same time and the number of cases of a special punishment of attempts, in cases where it is not possible to apply a basic rule, which relies on a prescribed punishment for a particular criminal offense.

Legal rule of culpability attempts is regulated through the guideline of "when the law expressly prescribes punishment for the attempt."

In this paper, the author shows in detail and analyzes all the special forms of criminality attempts, determining their representation, a catalog in Croatian criminal law, comparing the weight originally prescribed for a particular criminal offense which is extremely punishable attempt and analyzing their representation by each of the Penal Code .

Finally, it points out that the legislator decided to specifically punish attempt and for crimes in the domain of so-called bargain crime, with a prescribed prison sentence of up to one year, with a number of offenses with a prescribed prison sentence of up to three years, which indicates that the legislative solution that is necessary to incriminate special cases when the attempt of a crime must be punished, even if they are beyond the reach of the general rule the criminality of attempts.

Key words: attempt, regulation, extraordinary, legalisation of attempted criminal offense 